\title{
Correction to: Does Organizing Mentor-Mentee Matches into Small Groups Enhance Treatment Effects in a Site-Based Mentoring Program for Adolescents? Results of a Randomized Controlled Trial
}

\author{
Shelley A. Haddock ${ }^{1} \cdot$ Lindsey M. Weiler ${ }^{2} \cdot$ Hyanghee Lee $^{1} \cdot$ Kimberly L. Henry $^{1} \cdot$ Rachel Lucas-Thompson $^{1}$. \\ Toni S. Zimmerman ${ }^{1} \cdot$ Jennifer L. Krafchick ${ }^{1} \cdot$ Gereon F. Fredrickson $^{1} \cdot$ Neil Yetz $^{1} \cdot$ Lise M. Youngblade $^{1}$
}

Published online: 16 July 2020

(c) Springer Science+Business Media, LLC, part of Springer Nature 2020

Correction to: Journal of Youth and Adolescence https://doi.org/10.1007/s10964-020-01267-1

The original version of the article was inadvertently published without the text citation of the below listed references. The text with corrected citations and the references are given below:

In section "Campus Connections", first para, the sentence should read, "This 12-week preventive intervention targets at-risk adolescents through an intentional multi-level mentoring community facilitated by experienced mentor coaches and family therapists (See Weiler et al. 2015 for complete description)".

In the same section, first para, the sentence should read, "Youth are matched one-to-one with an undergraduate university student mentor who is enrolled in a 3-credit service learning course (cf Weiler et al. 2013)".

Following the same section, third para, the sentence should read, "A qualitative inquiry into the group experience found that these groups provided a place (a) for mentors to receive support and supervision, (b) for mentors and mentees to belong, and (c) for mentees to grow and learn (Weiler et al. 2014)" and last para, first sentence should read, "Results from two pilot studies of Campus Connections suggested positive impacts on adolescent problem behavior (Weiler et al. 2015) and youth-perceived

The original article can be found online at https://doi.org/10.1007/ s10964-020-01267-1.

\footnotetext{
Shelley A. Haddock

shelley.haddock@colostate.edu

1 Colorado State University, Fort Collins, CO 80523, USA

2 University of Minnesota, St. Paul, MN 55108, USA
}

improvements in school, relationships, self-esteem, future orientation, and behavior (Haddock et al. 2017)".

In section "Mentoring Groups", second para, the sentence should read, "Mentoring groups can provide a structure that allows matches to feel a sense of stability (Griffith et al. 2019) and mentors to easily access real-time support from one another in connecting with mentees (Weiler et al. 2014)".

In section "Practice Implications and Future Directions", last para, the sentence should read, "Qualitative evidence speaks to a potential role of mentoring groups in helping mentors build relationships with one another (Weiler et al. 2014), which may promote mentor satisfaction".

\section{References}

Haddock, S. A., Zimmerman, T. S., Thomas, A. G., Weiler, L. M., Krafchick, J., \& Fredrickson, G. J. (2017). A qualitative analysis of mentee experience in campus-based mentoring program. Journal of Youth Development, 12, 61-80. https://doi.org/10. 5195/jyd.2017.496.

Weiler, L. M., Haddock, S. A., Zimmerman, T. S., Henry, K. L., Krafchick, J. L., \& Youngblade, L. M. (2015). Time-limited, structured youth mentoring and adolescent problem behaviors. Applied Developmental Science, 19, 196-205. https://doi.org/10. 1080/10888691.2015.1014484.

Weiler, L., Haddock, S., Zimmerman, T. S., Krafchick, J., Henry, K., \& Rudisill, S. (2013). Benefits derived by college students from mentoring at-risk youth in a service-learning course. American Journal of Community Psychology, 52, 236-248. https://doi.org/ 10.1007/s10464-013-9589-Z.

Weiler, L. M., Zimmerman, T. S., Haddock, S. A., \& Krafchick, J. (2014). Understanding the experience of mentor families in therapeutic youth mentoring. Journal of Community Psychology, 42, 80-98. https://doi.org/10.1002/jcop.21595. 